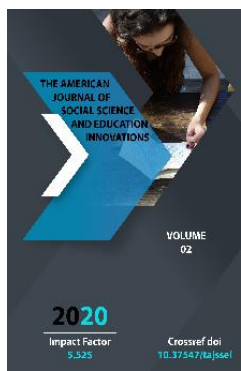

\title{
The Image Of Navoi In The Stories
}

Jumayev Zafar Hamdamovich

Phd, Associate Professor Of Navoi State Pedagogical Institute (Uzbekistan)

Journal Website:

http://usajournalshub.c

om/index,php/tajssei

Copyright: Original

content from this work

may be used under the

terms of the creative

commons attributes

4.0 licence.

\section{ABSTRACT}

The article examines the features of Uzbek folk historical legends, their role and composition of images in the system of folk prose. On the example of the analysis of folk legends about Alisher Navoi, oral stories about historical figures and artistic interpretation of life realities in an epic plot are highlighted.

\section{KEYWORDS}

Uzbek folklore, historical legends, epic plot, motif, historical prose, image, literary source, Genesis, plot structure.

\section{INTRODUCTION}

As you know, the historical traditions of the Uzbek people are characterized by a true reflection of reality based on real facts, an epic presentation of certain aspects of the life and activities of great people who lived in the past. Despite the fact that any historical fact is not the basis for a legend, as a result of the oral narration of life realities that have left a significant mark on the people's worldview, their thinking, the first story centers of historical legends appear. That is why the characters depicted in such stories are described with the enrichment of the narrative with epic interpretations based on fiction. In other words, the images depicted in stories about historical figures and historical events are not an exact copy of the image of people who existed in real life, but their visions that have become epic images.

\section{MATERIALS AND METHODS}

A distinctive feature of stories about historical figures is that they tell about real people who lived in the past, who won fame among the 
people with their works. The events told in such stories are perceived by the listener and the narrator as a real event in the life of a real historical person. Their storyline consists of historical facts and life fictions related to great personalities. The real reflection of reality, the viability of the image system, and the historical and ethnographic concreteness of the epic interpretation determine the specifics of the narrative about historical figures.

Stories about historical figures are told at meetings of the people, in conversations, when there is an interest in learning about specific events related to the past, there is a need to introduce into the consciousness of the young generation the instructive works, selflessness, heroism of the great personalities of our history. The plot system of stories of this type is based on historical reality and real reality, and contains various historical facts and information related to the lives and activities of real people. The plot of such stories is based on an epic interpretation of the image of the great moods that played an important role in the history of our people, since their interpretation is dominated by a lively imagination. Although the reality of life described in some stories consists of complete fiction, it has been preserved in the epic narrative.

Stories about historical figures were popular among the people in two ways: historical and literary sources and live performance of the oral epic tradition. The plot system of such stories was formed under the influence of the ancient traditions of the epic genres of Uzbek folklore and was improved thanks to the epic knowledge and performance skills of the rovians. In Uzbek folklore, an important place is occupied by legends associated with the names of great personalities who played an important role in the history of our people. The system of images of this type of narratives consists of great people, famous for their greatness, hard work and high talent, who selflessly worked for the sake of peace and prosperity of the people.

A large cycle of historical legends of the Uzbek people consists of folk works that tell about the great poet and thinker Alisher Navoi. Uzbek folk legends about Alisher Navoi A.K.Borovkov, M.Afzalov, N.Mallayev, T.Mirzayev, M.Jurayev, S.Umarov, A.Ergashev researched and the author of these lines. The stories of the great poet about his noble work for the benefit of the people and the prosperity of the country, about his superiority in the art of words, that he is known as the owner of large-scale thinking, became public. Such stories were later repeatedly reprinted in the people, they became variants, were enriched by a system of traditional plots and motifs related to the epic genres of Uzbek folklore, and became folk legends. In our opinion, three sources served as the basis for the formation of folk legends about Alisher Navoi: a) memoirs of contemporaries about the poet; $\mathrm{C}$ ) folk tales about the noble deeds of the poet; d) information given in historical sources about the poet.Linguists N.Yarashova, N.Sadinova, R.Yusubova, G.Boltayeva also in his research expressed their opinions about it.

The stories create a full-fledged artistic image of Alisher Navoi, whose image is embodied in the image of a great poet, a mature educator, a just statesman, a Patriotic personality and a pure human heart with vital features. In the legends included in the story series" wise Alisher", it is told that Alisher Navoi was an 
incredibly smart, resourceful and intelligent person. From the Uzbek Bakhshi Badulla OTA of Acute staying in Aravan district, Kyrgyz Republic, Professor M. In the story "the difference of truth and lies", written Muratovym, mind Navoi described as follows:

"One day in the presence of Alisher Navoi, sitting on the exercise on the lawn, one person came in and welcomed the darkness:

Navoi, khazrat, the question that has haunted me for many years, comes one day. After all, I should have come to you. Tell me, what is the difference between true and false? "what is it?" he asked.

Navoi placed the palm of his right hand on his lap and remained silent. Even though haligi stares, waiting for a response for quite a long time, in the end, patience fails:

- $\quad$ Navoi hazretleri, I regularly respond to you! - said. Navoi smiles:

- I Immediately answered your question, didn't I understand? - said.

You didn't open your mouth that LomMIM?! What's to understand? download free video / Silent.az

- $\quad$ in 2006, the city opened Russia's first international airport "Kazan", which was opened in 2007. It's true what you saw with your eyes, I mean what you hear with your ear will be a lie.

- People who admired the mind of Navoi:

- $\quad$ Ofarin! Relax your mind!»Debbie".

In this story, it is described that the sage Alisher Navoi very delicately answered the question of a person who came to learn the difference between lies and Truth: the difference between lies and Truth is visible to the naked eye-he "tells"the poet with gestures that there is a difference between hearing and hearing. At the same time, Navoi also answers the question whether he wants to try it. And the one who asks the question does not understand Navoi's gesture, that is, the answer. In this place, Alisher's wisdom, modernity, and extraordinary resourcefulness are described with exaggeration. The motif of answering a question with a gesture is also found in another legend associated with the name of Navoi.

In the story "head and tongue", it is said that " many compliments to Sultan Hussein Navoi concerned hashish of the ichikor Ministers, so they hated Navoi. One day they gave the king:

Why do you give two thousand coins to every word Alisherbek a? ! Don't we deserve such compliments?! the uproar raised.

Then the king, looking at his Ministers, pointed his head with his index finger. The Ministers, who did not understand anything, looked at each other, trembled and chatted, squeezing their shoulders. At this point, Mir Alisher also stuck out his tongue with his finger. Ministers who don't understand the meaning of these cryptic gestures are watching. The king, not understanding the meaning of these gestures, ordered his disconsolate-looking Ministers to give him three days ' respite, and during these three days to learn the meaning of the mysterious "conversation"between him and Mir Alisher. The Ministers divided the pickaxes, thought about it, but still couldn't find it. In the end, they were forced to bow down in front of Navoi. Mir Alisher also gave the mouths of these Ministers:in 2014, Uzbekistan issued a first. 


\section{RESULTS AND DISCUSSIONS}

Thus, the plot of the fairy tales "the difference between truth and lies"," head and tongue " is based on one of the traditional motifs of the Uzbek folk tale - the riddle of gestures. In both stories, the riddle of the gesture serves to demonstrate the wisdom of Navoi, its execution and solution is associated with the image of Alisher Navoi. The motif of the riddle with gestures in the stories was used for two different purposes: first, through such mysterious actions as"conversation" - a characteristic to show the greatness of the perfection of the mind of the Wise Navoi, who is able to Express his thoughts through gestures with extraordinary tenderness; second, to laugh at the ignorance of ignorant and greedy Ministers.

Alisher Navoi, who passionately creates in the story "the difference between lies and Truth", answering a question about a person who has an extraordinary imagination, miraculously answers: he thinks of his lines, which he hasn't written yet, until he has pressed the paper, until he has put the paw of his right hand on his lap. The great poet wanted to try out a person who came with such a gesture that, if he were a sober person, he would understand himself and not interfere with the owner's busy pencil in a creative rush. But after the future Navoi looked at his answer "regularly", the great poet showed him sympathy and explained in detail the meaning of his gestures.

The story "head and tongue" also notes that the" conversation " that took place between Alisher Navoi and Sultan Hussein is aimed at testing ignorant and ignorant Ministers. By order of Sultan Hussein, the Ministers who were supposed to know the secret of the muhlat riddle within three days will be forced to hit their heads on the threshold of noyloy Mir Alisher. Tradition has it that when the riddle was uttered, who could not find the meaning in the riddle, it was required to fulfill some condition of circumnavigation. The story also traces the artistic expression of this tradition: Mir Alisher asks for forty thousand coins from visiting Ministers to learn the meaning of gestures. The solution of the riddle with gestures is associated with the name of Alisher Navoi, first, if he shows his wisdom, and second, ichikora reveals the ugly prophecies of the Ministers.

The story" Navoi and mardikor "tells how a young man, being courageous, forgives days by" suppressing quarrels between people on his way when someone's cart gets stuck in the mud", "da-halashib", "da-halashib", touching the help of the people. Alisher Navoi, who saw humanity in this young man, respected him and welcomed him when he saw it. Surprised by this attitude of Navoi, the young man, being a godfather, sooner or later gets on the knees of the mosque, having nothing to do with anyone. When Alisher Navoi saw this young man, he could not help but respect him as before, and not even greet him. Editorial office address: 6 tallimarjon street, Tashkent, 100105. responsible editor:

You went to people who were shouting and shouting. Now, if you are sitting on the dining Board face to face with Breakfast from morning to night. That's why I can't get Hello! founder: editorial office of the newspaper "Xabar". Severely affected by Navoi's words, the young man left the mosque to continue his previous training.

The image of Alisher Navoi, depicted in folk tales, is primarily a symbol of a wise, very 
intelligent, noble and generous person. At the same time, the stories pay special attention to the fact that Navoi is a poet, a master of fine words. Some stories tell about Navoi's high artistic skill and creative process ("book handling with dilor", "the story of a matlau", "a girl's joke") and the history of creating some of his works related to his pen, and some ("agerlarni Mai ILA shod etish", "Navoi and Kozi Kalon") say that Navoi's power in badiha is high.

\section{CONCLUSION}

Uzbek folk historical legends about Alisher Navoi are one of the characteristic manifestations of the epic interpretation of reality, which arose on the basis of ancient traditions of folk prose. The plot of the story is based on memories and stories about the poet. The great poet led a noble work to improve the way of life of the common people, improve the country, create peace and tranquility of the people. Such his instructive activity contributed to the formation of an unusual attitude towards him among the people. Various oral stories, memories of every noble deed of Navoi were passed from mouth to mouth. In the process of widespread popularization within the epic tradition of realistic expression set forth in these stories, historical legends about Alisher Navoi were formed.

\section{REFERENCES}

1. Borovkov A.K. Navoi and Jami in the folk tradition// Izvestia of the USSR Academy of Sciences. Dept. the tongue also burns. Issue 6. - M., 1947, volume Yu.I.S. 481492.
2. Afzalov M. Folk legends about Navoi // Shark yulduzi. - Tashkent, 1948. - No. 5. P.25-31.

3. Mallayev N. AlisherNavoi and folk art. Tashkent: Publishing house of literature and art, 1974. -P.372.

4. Mirzayev T., Jo'rayev M. Folk legends about AlisherNavoi and their sources // Social sciences in Uzbekistan. - Tashkent, 1991. - №8. -B.40.

5. Umarov S. Legend and history // Uzbek language and literature. - Tashkent, 1983. -№2. -B.49-52.

6. Ergashev A. The legend and its place in the plot-compositional construction of the work of art: PhD. Samarkand: 1994.

7. Jumayev Z. Alisher Historical legends about Navoi // Adabiyotgulshani. Research on Uzbek philology. Book 1. Navoi, 1999. -P. 35-39.

8. Muhamadjonovna, S. D. (2020). The key concepts of forming sociolinguistic competence of future English language specialists. Asian Journal of Multidimensional Research (AJMR), 9(5), 118-121.

9. Muhamadjonovna, S. D. (2020). The development of sociolinguistic competence of future English language teachers through computer technologies. European Journal of Research and Reflection in Educational Sciences, 8 (3) Part II, 147-150.

10. Ярашова, Н. Ж. (2019). ПРОЯВЛЕНИЕ ИНТОНАЦИИ У ДЕТЕЙ ПОСРЕДСТВОМ ОБРАЩЕНИЯ. In ТРадИциИ И НовациИ В профессиональной подготовке и деятельности педагога (рр. 128-130).

11. Jumaevna, Y. N. (2020). Occupation of the child's personal mental status in dialogual speech. Asian Journal of 
Multidimensional Research (AJMR), 9(5), 405-408.

12. Jumayevna, Y. N. (2019). Linguo culture logical features of metaphors in children's literature (On the example of khudayberdi tokhtabayev's creative work). ACADEMICIA: An International Multidisciplinary Research Journal, 9(4), 139-145. 